\title{
The equine arteritis virus isolate from the 2010 Argentinian outbreak
}

\author{
G.E. Metz ${ }^{(1,2)}$, M.S. Serena (3) C.J. Panei ${ }^{(2,3)}$, E.O. Nosetto (1) \\ \& M.G. Echeverría ${ }^{(1,2)^{*}}$ \\ (1) Virology, Faculty of Veterinary Sciences, National University of La Plata, 60 and 118, CC 296, \\ 1900 La Plata, Argentina \\ (2) Members of the Consejo Nacional de Investigaciones Científicas y Técnicas - \\ Centro Científico Tecnológico (National Scientific Research Council), La Plata, Argentina \\ (3) Immunology, Faculty of Veterinary Sciences, National University of La Plata, 60 and 118, CC 296, \\ 1900 La Plata, Argentina \\ *Corresponding author: gecheverria@fcv.unlp.edu.ar; mariagabrielaecheverria@yahoo.com.ar
}

\section{Summary}

A semen sample from a stallion infected during the 2010 equine arteritis virus (EAV) outbreak was received for viral isolation prior to castration of the animal. The virus was identified using a polyclonal antibody immunofluorescence test. Reverse-transcription polymerase chain reaction (RT-PCR) was used to amplify a region of the GP5 gene with primers GL105F and GL673R. The PCR products were purified and sequences of both strands were determined in a MegaBACE ${ }^{\text {TM }}$ 1000 with inner primers CR2 and EAV32. A phylogenetic dataset was built with the previously reported sequences of five strains isolated in Argentina, together with a group of selected sequences obtained from GenBank. The unrooted neighbourjoining tree was constructed using molecular evolutionary genetic analysis (MEGA) and bootstrap analyses were conducted using 1,000 replicate datasets. Evolutionary distances were computed using the maximum composite likelihood method. A NetNGlyc server analysis at the Technical University of Denmark (www.cbs.dtu.dk/services/NetNGlyc/) was used to predict N-glycosylation in GP5 sequences. The phylogenetic analysis revealed that the new strain (GLD-LP-ARG), together with other strains previously isolated, belongs to the European group EU-1 but in a different branch. The new strain shows $99 \%$ nucleotide identity with strain A1 and 98.1\% with the Belgian strain 08P178. Persistently infected stallions and their cryopreserved semen constitute a reservoir of EAV, which ensures its persistence in the horse population around the world. These findings reinforce the importance of careful monitoring of persistently infected stallions, as well as semen straws, by RT-PCR or test mating, in accordance with national regulations.

\section{Keywords}

Argentina - Equine arteritis virus - Outbreak - Semen sample.

\section{Introduction}

Equine arteritis virus (EAV) was first isolated from fetal lung tissue during an outbreak of respiratory disease and abortion in Bucyrus, Ohio, in the United States of America (USA) (1). Until 2010, the prevalence of EAV-infected stallions resident in Argentina was thought to be very low. The first report of serological evidence was in 1984 (2), when a prevalence of $9.2 \%$ was found in the population of warmblood horses sampled. The virus (strain LP01) was first isolated in 2001 (3); later, strain LT-LP-ARG was isolated from the testicle of a seropositive stallion that had been imported into Argentina in 1998 (4). In 1998, several EAV antibody-positive animals were detected in two sporthorse breeding farms that practised artificial insemination with imported semen. A follow-up study between July 2001 and December 2003 found a prevalence of $45.8 \%$ in one 
of those farms; three stallions were virus isolation-positive (strains LP02/R, LP02/C, LP02/P) (5). Three new sequences of EAV from three archive semen samples were obtained in 2008: one (RO-LP-ARG) from a stallion housed on the breeding farm where the first strain of EAV was isolated and the other two (RZ-LP-ARG, KB-LP-ARG) from the farm where the LP02 strains had been isolated (6). Before the 2010 occurrence of equine viral arteritis in Argentina, the virus had not been involved in respiratory disease, abortion or foal death; the prevalence was restricted to sport-horse breeds and to certain breed lineages (7). Phylogenetic investigations of the virus have focused on the hypervariable region of the GP5 gene, in both European and North American strains $(8,9,10)$. At present, Argentinian EAV strains all belong to the same group $(6,11,12)$. Although infrequently reported in the past, confirmed outbreaks of arteritis appear to be on the increase and in the past decade the disease has been reported in the USA (13), France (14) and Belgium (15). Analysis of phylogenetic relationships has been demonstrated to be an effective tool in tracing the source of EAV infection.

In 2010, two mares on a thoroughbred breeding farm in Buenos Aires Province seroconverted after insemination with frozen semen imported from the Netherlands. The semen straws from the stallion believed to be responsible for spreading the infection were submitted to the Virology Laboratory, National Institute of Agricultural Technology, Castelar, Buenos Aires, and EAV was isolated (16). Four other farms that had used this semen were put into quarantine and all the mares that had been inseminated with the infective semen were found to be seropositive.

A high prevalence of EAV infection was also found at an equestrian club located in central Buenos Aires, where two other mares had been inseminated with infective semen from a stallion housed at the club. Respiratory disease, fever, limb oedema and abortions were observed during this outbreak. Twenty-seven jumping stallions seroconverted and 22 persistently infected stallions were castrated. In the present study, the ORF5 region of this EAV strain was analysed genetically and compared with sequences of other strains from Argentina and elsewhere.

\section{Materials and methods}

\section{Sample processing and virological methodology}

The infected stallion at the equestrian club in central Buenos Aires was a Hanoverian born in 2000 that had been housed at the club since 2006; the horse was found to be seropositive in May 2010. Before castration of the animal, a semen sample was processed for routine virus isolation at the Virology Laboratory, Faculty of Veterinary Sciences, National University of La Plata, as described previously (3, 17). Briefly, serial tenfold dilutions $\left(10^{-1}\right.$ to $\left.10^{-3}\right)$ of the sample were inoculated in duplicate onto RK13 cells grown in six-well plates. The cellswere maintained in culture medium containing $2 \%$ fetal bovine serum. Plates were incubated at $37^{\circ} \mathrm{C}$ in an atmosphere of $5 \% \mathrm{CO}_{2}$ and examined daily for cytopathic effects. The virus was identified using a polyclonal antibody immunofluorescence test, as described previously (3).

\section{Reverse-transcription polymerase chain reaction and sequencing}

Viral RNA was extracted from $500 \mu \mathrm{l}$ of the supernatant of infected RK13 cells with $500 \mu$ l of TRIzol ${ }^{\circledR}$ (Invitrogen) and precipitated with isopropanol. Portions $(5 \mu \mathrm{l})$ of RNA resuspended in distilled water were used for cDNA synthesis using reverse transcriptase and random hexamers (Promega). For PCR amplification, the primers GL105F and GL673R, which flank a 546-nt region of the GP5 gene, were used (18). Denaturation, annealing and extension consisted of 35 cycles at $94^{\circ} \mathrm{C}$ for $45 \mathrm{~s}, 60^{\circ} \mathrm{C}$ for $1 \mathrm{~min}$ and $72^{\circ} \mathrm{C}$ for $90 \mathrm{~s}$, respectively. The PCR products were run on $2 \%$ agarose gels, stained with ethidium bromide, observed under UV light and purified using a PCR purification kit. The sequences of both strands were determined in a MegaBACE ${ }^{\mathrm{TM}} 1000$ with primers CR2 and EAV32, which flank a 519-nt region (8).

\section{Dataset and phylogenetic analysis}

The phylogenetic dataset was built with five strains isolated in Argentina, sequences reported previously (3, 4, 5, 6, 11), and a group of selected sequences obtained from GenBank (Table I). Sequences were edited using BioEdit software version 5 (19) and aligned in molecular evolutionary genetic analysis (MEGA) software, version 4.0, using the ClustalW algorithm. Sequence pair distances were calculated by DNAstar $^{\circledR}$ (20). The unrooted neighbour-joining tree was constructed using MEGA and bootstrap analyses were conducted using 1,000 replicate datasets. Evolutionary distances were computed using the maximum composite likelihood method (20).

\section{Analysis of $\mathbf{N}$-glycosylation sites}

A NetNGlyc server analysis at the Technical University of Denmark (www.cbs.dtu.dk/services/NetNGlyc/) was used to predict N-glycosylation in GP5 sequences. This program predicts asparagines to be $\mathrm{N}$-glycosylated according to the Asn-Xaa-Ser/Thr sequons (where Xaa is not Pro), with a threshold of 0.5 . 
Table I

Origins, names and phylogenetic groups of the equine arteritis virus strains used in this study

\begin{tabular}{|c|c|c|c|}
\hline Virus strain & Country of isolation & GenBank accession no. & Phylogenetic group \\
\hline F5 & France & EF492543 & NA \\
\hline F6 & France & EF492544 & NA \\
\hline F7 & France & EF492545 & NA \\
\hline F8 & France & EF492546 & NA \\
\hline F9 & France & EF492547 & EU-1 \\
\hline F10 & France & EF492548 & EU-2 \\
\hline F11 & France & EF492549 & NA \\
\hline $\mathrm{F} 12$ & France & EF492550 & NA \\
\hline $\mathrm{F} 13$ & France & EF492551 & NA \\
\hline F14 & France & EF492552 & NA \\
\hline F15 & France & EF492553 & EU-2 \\
\hline F23 & France & EF492561 & EU-1 \\
\hline F24 & France & EF492562 & NA \\
\hline F25 & France & EF492563 & NA \\
\hline F26 & France & EF492564 & NA \\
\hline $\mathrm{H} 2 \mathrm{O}$ & Hungary & AY453305 & EU-1 \\
\hline $\mathrm{H} 21$ & Hungary & AY453306 & EU-1 \\
\hline $\mathrm{H} 22$ & Hungary & AY453307 & EU-1 \\
\hline $\mathrm{H} 23$ & Hungary & AY453308 & EU-1 \\
\hline $\mathrm{H} 24$ & Hungary & AY453309 & EU-2 \\
\hline 113 & Italy & AY453310 & EU-1 \\
\hline 114 & Italy & AY453311 & NA \\
\hline 115 & Italy & AY453312 & NA \\
\hline 116 & Italy & AY453313 & EU-1 \\
\hline 117 & Italy & AY453314 & EU-1 \\
\hline 118 & Italy & AY453315 & EU-1 \\
\hline 119 & Italy & AY453316 & NA \\
\hline 120 & Italy & AY453317 & EU-1 \\
\hline PLA00-1 & Poland & EF102348 & EU-1 \\
\hline PLB01-1 & Poland & EF102349 & EU-1 \\
\hline PLG02-1 & Poland & EF102354 & EU-1 \\
\hline PLK02-8 & Poland & EF102363 & EU-1 \\
\hline PLH05-1 & Poland & EF102355 & EU-1 \\
\hline J25-941109-3 & South Africa & AY956603 & EU-2 \\
\hline J7-931125 & South Africa & AY956602 & EU-2 \\
\hline J6-940309 & South Africa & AY956601 & EU-2 \\
\hline J5-940309 & South Africa & AY956600 & EU-2 \\
\hline J4-931209 & South Africa & AY956599 & EU-2 \\
\hline J3-931209 & South Africa & AY956598 & EU-2 \\
\hline J2-931125 & South Africa & AY956597 & EU-2 \\
\hline J1-931125 & South Africa & AY956596 & EU-2 \\
\hline RSA1 & South Africa & AY453332 & EU-2 \\
\hline RSA2 & South Africa & AY453333 & NA \\
\hline RSA3 & South Africa & AY453334 & EU-1 \\
\hline RSA4 & South Africa & AY453335 & EU-1 \\
\hline RSA5 & South Africa & AY453336 & EU-1 \\
\hline RSA6 & South Africa & AY453337 & EU-1 \\
\hline RSA7 & South Africa & AY453338 & EU-1 \\
\hline RSA8 & South Africa & AY453339 & EU-1 \\
\hline S2 & Sweden & AY453340 & EU-2 \\
\hline S3 & Sweden & AY453341 & EU \\
\hline S4 & Sweden & AY453342 & EU \\
\hline S5 & Sweden & AY453343 & EU-2 \\
\hline
\end{tabular}


Table I (cont.)

\begin{tabular}{lccc}
\hline Virus strain & Country of isolation & GenBank accession no. & Phylogenetic group \\
\hline S6 & Sweden & AY453344 & EU-2 \\
S7 & Sweden & AY453345 & EU-2 \\
S-113 & Netherlands & AF099833 & NA \\
S-544 & New Zealand & AF099834 & NA \\
SWZ64 & Switzerland & U38609 & EU \\
KY84 & USA & AF107279 & NA \\
KY93 & USA & U81017 & NA \\
VBS53 & USA & U81013 & NA \\
D84 & USA & AF107266 \\
E85 & USA & AF107275 & NA \\
G1 & USA & AF118777 & EU-1 \\
P1 & UF118775 & EU-1 \\
R1 & UF118773 & EU-1 \\
A1 & USA & AF118769 & EU-1 \\
MT89 & USA & U38604 & NA \\
08P178 & USA & JN254761 & EU-1 \\
LP01 & Belgium & DQ435439 & EU-1 \\
LP02/R & Argentina & DQ435440 & EU-1 \\
LP02/C & Argentina & DQ435441 & EU-1 \\
LP02/P & Argentina & DQ435442 & EU-1 \\
LT-LP-ARG & Argentina & EU622859 & EU-1 \\
KB-LP-ARG & Argentina & EU622860 & EU-1 \\
RZ-LP-ARG & Argentina & EU622861 & EU-1 \\
R0-LP-ARG & Argentina & EU622862 & EU-1 \\
GLD-LP-ARG & Argentina & J0316510 & EU-1 \\
\hline FU: Ewron & Argentina & &
\end{tabular}

NA: European

\section{Results}

\section{Viral isolation and reverse-transcription polymerase chain reaction}

After two passages in confluent monolayers of RK13 cells, cytopathic effects were observed in cells inoculated with the seminal plasma at $10^{-1}$ and $10^{-2}$ dilutions when compared with control cells. The isolated virus strain was named GLD-LP-ARG. After reverse transcription, cDNA was obtained from the supernatants of the cultures. An immunofluorescence test confirmed the presence of EAV antigen; no virus-specific fluorescence was observed in control mock-infected cells. Using primers specific for the GP5 gene, the cDNA gave a visible 591-bp band in an ethidium bromide-stained agarose gel. No bands were observed in the negative control used in the PCR. The 519bp sequence was analysed and aligned with the Argentinian EAV isolates and sequences previously reported, and also with American and European reference strains.

\section{Phylogenetic analysis}

The partial nucleotide sequence data for gene GP5 reported here have been previously submitted to GenBank under accession number JQ316510. The distance tree obtained by the neighbour-joining algorithm showed that all the Argentinian sequences, except for the first isolate (LP01), are clustered together with high bootstrap values. However, the new isolate, GLD-LP-ARG, is closely related to strains P1, R1, A1, G1, H20, H22, F23 and 08P178, with LP01 as the most basal strain of EAV in the EU-1 subgroup (Fig. 1). Use of other algorithms such as maximum likelihood revealed the same topology: one group comprises the LP02 strains (LP02/R, LP02/C, LP02/P), LT-LP-ARG, RZ-LP-ARG, RO-LP-ARG and KB-LP-ARG; another comprises some European strains and GLD-LP-ARG, with the LP01 strain being the most basal of the group (Fig. 1). The percentage identity among the EAV sequences from the EU-1 clade where the Argentinian strains are located varied between $87.8 \%$ and $100 \%$. Strain GLD-LP-ARG shares 99\% nucleotide identity with strain $\mathrm{Al}$ and $98.1 \%$ with the Belgian strain 08P178.

\section{Analysis of $\mathbf{N}$-glycosylation sites}

Changes in GP5 in the Argentinian sequences are described below. The deduced amino acid sequences (51-222) of the variable and conserved regions of the protein are illustrated in Fig. 2. There are no deletions or insertions. In the first constant region $(\mathrm{Cl})$, the only substitution that was found had already been reported (position 57 Cys x Trp in strain 


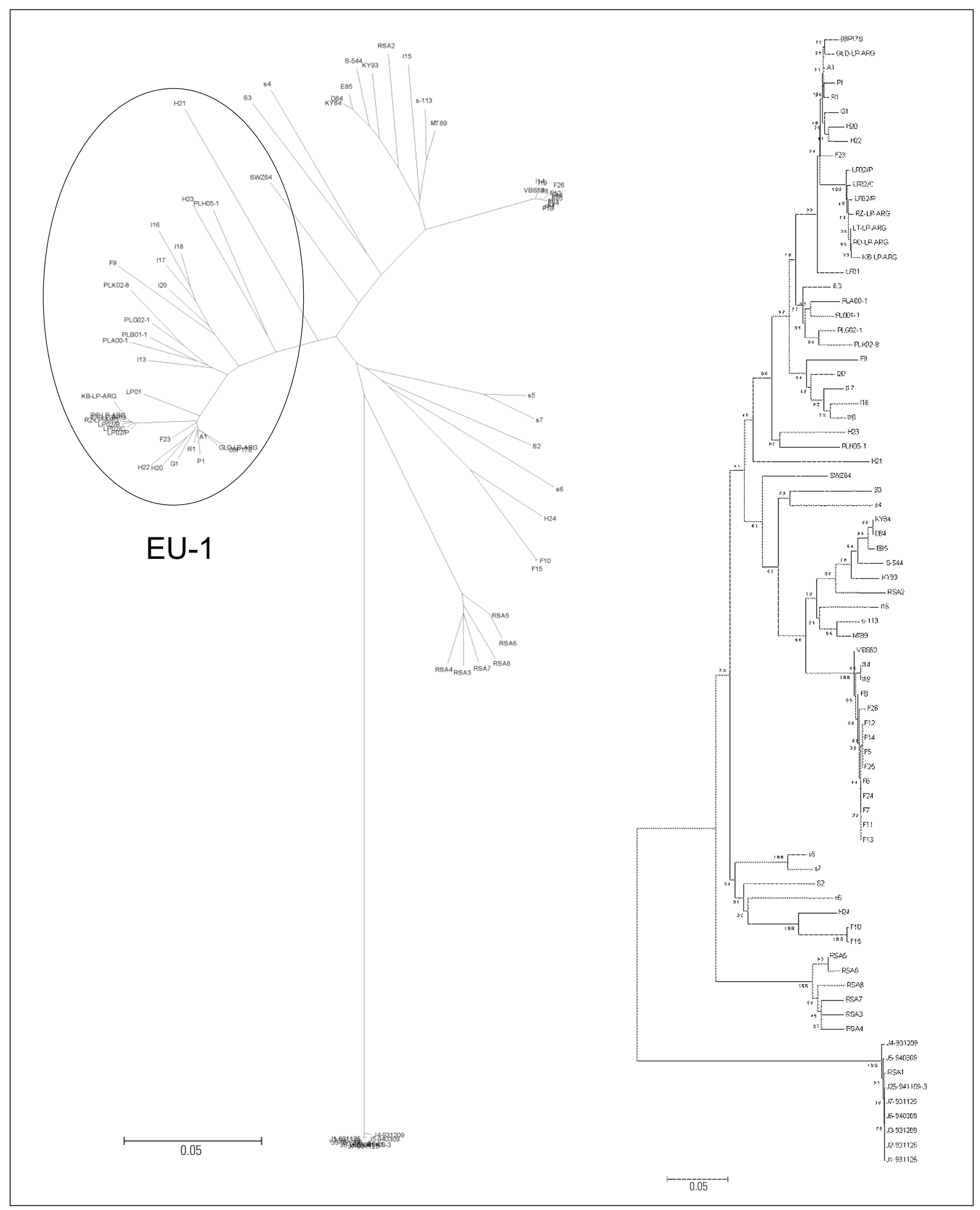

EU-1: European sub-group 1

Fig. 1

Maximum likelihood phylogenetic tree based on analysis of ORF5 nucleotide sequences in equine arteritis virus strains Bootstrapping of the tree was carried out in 1,000 duplicates using the MEGA 4.0 software program 


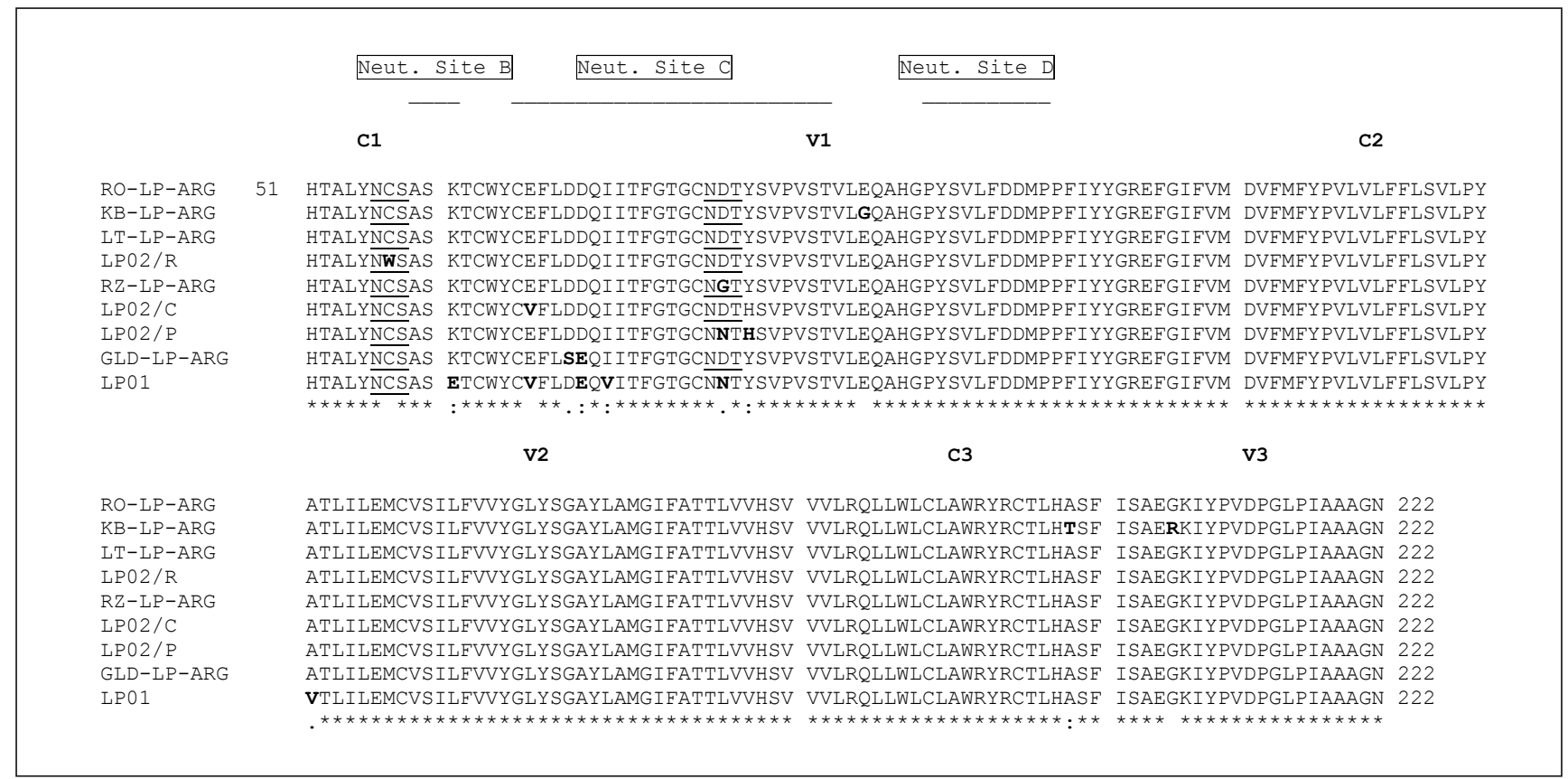

Fig. 2

Alignment of deduced amino acids for partial GP5 sequences of variable and conserved regions of Argentinian equine arteritis virus strains

Non-consensus amino acids are in bold letters. Neutralisation sites B, C and D are indicated in boxes.

Predicted N-glycosylation sites are underlined

LP02/R) (12). The second constant region (C2) remained invariable in all the sequences and the third constant region (C3) showed only substitution in KB-LP-ARG (position 199 Ala $\mathrm{x}$ Thr). Analysis of the V1 region (amino acids 61-121) showed that Cys in positions 63, 66 and 80 remained invariable in all the Argentinian sequences. As previously reported (12), neutralising site C (amino acids 67-90) was hypervariable. However, one change (position 70 Asp x Ser) was new for sequences in the 2010 outbreak strain (GLDLP-ARG). In contrast, Asp x Glu (position 71) appeared in both GLD-LP-ARG and LP01 (the first strain isolated in Argentina), and Glu x Gly (position 93) appeared in KBLP-ARG. Regarding amino acids 81-84, when analysing the putative N-linked glycosylation sites, all the sequences showed asparagine sites at amino acid 81 (variable) and in position 56 (conserved and critical for virus infectivity). It has been reported that loss of glycosylation sites in other arteriviruses can alter the virulence and tropism of the virus but it is not known whether these changes play an analogous role in EAV (21). However, according to the prediction glycosylation program used here, the asparagines present in position 81 were not sufficient to glycosylate in strains LP01 and LP02/P.

\section{Discussion}

Most EAV strains belong to one of three large genetic groups (EAV-1, EAV-2, EAV-3) (18). This classification has been modified recently as a North American clade (NA, formerly EAV-2) and a European clade (EU) with two subgroups (EU-1 and EU-2, formerly EAV-1 and EAV-3, respectively) (21). This approach has also been used to construct the phylogeny of isolates in Poland (22), where 44 isolates are included in the European subgroups (EAV-1 or EAV-3). The new Argentinian strain shares similarity with several European phylogenetic strains such as H2O and H22 (Hungary), F23 (France) and 08P178, the last strain isolated from an outbreak in Belgium, as well as with P1, R1, Al and G1 isolated in the USA (15). Strain S-113 from the Netherlands belongs to the North American group. To date, none of the Argentinian strains has been linked to the North American EAV strains. Differences are mostly localised in the $\mathrm{Vl}$ region, in particular within the neutralisation sites B, C and D. As previously reported, South African donkey isolates were classified in subgroup EU-2 but formed only one cluster (21). Furthermore, six isolates from Lipizzaner stallions in South Africa belonged to subgroup EU-1 and did not cluster with the South African asinine strains, thus representing a unique variant (21). As expected, some sequences, such as H21, SWZ64, S3 and S4, did not form statistically supported clusters and therefore formed an unclassifiable group of highly variable sequences branching off near the centre.

According to data from the Argentinian authorities, EAV was isolated from the imported semen of a stallion in the Netherlands. Some Argentinian premises were infected as 
a consequence of using the infective semen or through the movement of infected horses without observation of clinical signs after spread of the virus via the respiratory route. In the present study, a stallion housed in an equestrian club was castrated because it was persistently infected and shedding the virus in semen. The prevalence of infection at the club was very high (80\%). The genetic characterisation reported here confirms that the strain from the 2010 Argentinian outbreak belongs to subgroup EU-1, together with all the Argentinian sequences reported to date.

Previously, all Argentinian isolates were related to a nonpathogenic strain and this is the first report of an EAV isolate associated with clinical signs in Argentina. Regarding virulence, EAV strains can be classified as velogenic, mesogenic or lentogenic, according to the clinical signs (23): velogenic strains cause fatal disease in adult horses, mesogenic strains cause less severe disease and lentogenic strains do not cause any clinical signs. Loss of virulence in EAV has been related to the amino acids sequences of structural and nonstructural proteins, and eight critical amino acid substitutions in the structural protein GP5 have been identified as being responsible for EAV attenuation (23). The same amino acid substitutions were observed in the present study when comparing velogenic and mesogenic strains (23). Although the amino acid substitutions of the 2010 EAV Argentinian isolate related to a high- or mediumvirulence strain, analysis of strain virulence is more complex; GP5 analysis alone provides an approximation, but analysis of other structural and nonstructural proteins is required. Further, host genetic factors such as the haplotype of the equine could determine resistance or susceptibility to EAV infection and thus influence the capability of the virus to generate clinical signs (24).

In summary, the EAV-infected equine population in Argentina in 2010 showed mild clinical signs that could be correlated by analysing the sequence of gene GP5. Using amino acid substitution, the 2010 isolate was grouped with velogenic or mesogenic strains (23). According to the phylogenetic study, this strain has high similarity with the Belgian strain 08P178, also reported as a European subtype of low virulence (25). The Belgian strain was used recently in an experimental infection in naive ponies (26) where it produced mild clinical signs when compared with North American strains (27). It was concluded that the differences in clinical signs may be dependent on both the viral strain and the breed of animal (26).

Stallions and their cryopreserved semen constitute a reservoir of EAV, thus ensuring persistence of the virus in the horse population around the world and causing new outbreaks such as that in Argentina in 2010. These findings reinforce the importance of careful monitoring of EAV in persistently infected stallions, as well as in semen straws, by RT-PCR or test mating, according to national regulations. Although most EAV strains are of low virulence, outbreaks with severe clinical signs may occur.

\section{Conclusion}

The new Argentinian strain shows 99\% nucleotide identity with strain A1 and 98.1\% with the Belgian strain 08P178.

\section{Acknowledgements}

The assistance of Ms A. Conde and Mr C. Leguizamon is very gratefully acknowledged. 


\title{
Isolement du virus de l'artérite équine \\ responsable du foyer survenu en Argentine en 2010
}

\author{
G.E. Metz, M.S. Serena, C.J. Panei, E.O. Nosetto \& M.G. Echeverría
}

\section{Résumé}

Un échantillon de semence prélevé d'un étalon infecté lors du foyer d'artérite virale équine survenu en 2010 a été soumis à des analyses visant à isoler le virus avant de procéder à la castration de l'animal. Le test d'immunofluorescence recourant aux anticorps polyclonaux a été utilisé pour identifier le virus. L'amplification en chaîne par polymérase couplée à une transcription inverse (RT-PCR) a permis d'amplifier une région du gène GP5 au moyen des marqueurs GL105F et GL673R. Après avoir purifié les produits de la PCR, des séquences de chacun des deux brins ont été déterminées au moyen du séquenceur MegaBACE ${ }^{\mathrm{TM}} 1000$ en utilisant les marqueurs internes CR2 et EAV32. Un jeu de données phylogénétiques a été produit en utilisant les séquences identifiées au préalable à partir de cinq souches isolées en Argentine, parallèlement à une sélection de séquences émanant de GenBank. Un arbre non enraciné obtenu au moyen de l'algorithme de recherche des voisins (neighbour-joining) a été construit au moyen de MEGA (Molecular Evolutionary Genetic Analysis) et la méthode du bootstrap a permis d'analyser 1000 jeux de données de réplication. Les distances évolutives ont été calculées en appliquant la méthode du maximum de vraisemblance composite. Une prédiction des sites de $\mathrm{N}$-glycosylation des séquences GP5 a été réalisée grâce à l'outil analytique disponible sur le serveur NetNGlyc de l'Université technique de Danemark (www.cbs.dtu.dk/services/NetNGlyc/). L'analyse phylogénétique a révélé que la nouvelle souche (GLD-LP-ARG), ainsi que d'autres souches isolées précédemment, appartenaient au groupe européen EU-1 et qu'elles étaient placées sur une branche distincte de l'arbre. Les séquences de nucléotides de la nouvelle souche ont présenté un pourcentage d'identité de $99 \%$ avec celles de la souche $\mathrm{A} 1$ et de $98,1 \%$ avec celles de la souche belge 08P178. Les étalons porteurs chroniques du virus et leurs stocks de semence congelée constituent un réservoir du virus de l'artérite équine, principale cause de la persistance de cette maladie dans la population équine du monde entier. Ces résultats corroborent l'importance d'assurer un suivi attentif des étalons porteurs chroniques du virus ainsi que des paillettes de semence, en faisant appel à la RT-PCR ou aux tests de saillie, suivant la réglementation nationale.

\section{Mots-clés}

Argentine - Échantillon de semence - Foyer - Virus de l'artérite équine. 


\title{
El virus de la arteritis equina aislado a partir del brote argentino de 2010
}

\author{
G.E. Metz, M.S. Serena, C.J. Panei, E.O. Nosetto \& M.G. Echeverría
}

\section{Resumen}

Se recibió una muestra de semen extraída de un semental que había resultado infectado por el virus de la arteritis equina durante el brote de 2010, muestra que debía ser sometida a la técnica de aislamiento vírico antes de la castración del animal. Para identificar el virus se empleó una prueba de inmunofluorescencia con anticuerpos policlonales. Se procedió a amplificar una región del gen GP5 del virus por reacción en cadena de la polimerasa acoplada a transcripción inversa (RT-PCR) con los cebadores GL105F y GL673R. Tras purificar el producto resultante de la PCR se determinaron las secuencias de ambas hebras en un MegaBACE $^{\mathrm{TM}} 1000$ con los cebadores internos CR2 y EAV32. Paralelamente se generó un conjunto de datos filogenéticos con las secuencias de cinco cepas previamente aisladas en Argentina y otras varias secuencias obtenidas de GenBank. Aplicando el programa MEGA (Molecular Evolutionary Genetic Analysis) y el algoritmo de "unión de vecinos" (neighbour-joining) se obtuvo un árbol no enraizado de parentesco filogenético, tras lo cual se efectuaron análisis de remuestreo (bootstrap) con 1000 réplicas del conjunto de datos. El cálculo de las distancias evolutivas se realizó por el método de la máxima verosimilitud compuesta. Para predecir la N-glicosilación en las secuencias del gen GP5 se empleó un análisis disponible en el servidor NetNGlyc de la Universidad Técnica de Dinamarca (www.cbs.dtu.dk/services/NetNGlyc/). El análisis filogenético reveló que la nueva cepa (GLD-LP-ARG), como otras cepas aisladas previamente, pertenece al grupo europeo EU-1, aunque se ubica en una rama distinta. La nueva cepa presenta un $99 \%$ de identidad nucleotídica con la cepa A1 y un $98,1 \%$ con la cepa belga 08P178. Los sementales con infección persistente y su semen criopreservado constituyen un reservorio de virus de la arteritis equina que asegura su persistencia en la población caballar de todo el mundo. Las conclusiones de este estudio ponen de relieve la importancia de ejercer un estricto control de los sementales con infección persistente y de las pajuelas de semen, ya sea con la técnica de RT-PCR o con "pruebas de monta", según disponga la normativa de cada país.

\section{Palabras clave}

Argentina - Brote - Muestra de semen - Virus de la arteritis equina.

\section{References}

1. Doll E.R., Bryans J.T., McCollum W.H. \& Crowe M.E.W. (1957). - Isolation of a filterable agent causing arteritis of horses and abortion in mares; its differentiation from the equine abortion (influenza) virus. Cornell Vet., 47 (1), 3-41.

2. Nosetto E.O., Etcheverrigaray M.E., Oliva G.A., González E.T. \& Samus S.A. (1984). - Equine viral arteritis: detection of antibodies of horses in Argentina. Zentralbl. Veterinärmed., B, 31 (7), 526-529
3. Echeverría M.G., Pecoraro M.R., Galosi C.M., Etcheverrigaray M.E. \& Nosetto E.O. (2003). - The first isolation of equine arteritis virus in Argentina. Rev. sci. tech. Off. int. Epiz., 22 (3), 1029-1033.

4. Metz G.E., Serena M.S., Ocampos G.M., Panei C.J., Fernández V.L. \& Echeverría M.G. (2008). - Equine arteritis virus: a new isolate from the presumable first carrier stallion in Argentina and its genetic relationships among the four reported unique strains. Arch. Virol., 153 (11), 2111-2115. 
5. Echeverría M.G., Díaz S., Metz G.E., Serena M.S., Panei C.J. $\&$ Nosetto E.O. (2007). - Genetic typing of equine arteritis virus isolates from Argentina. Virus Genes, 35 (2), 313-320.

6. Metz G.E., Serena M.S., Díaz S. \& Echeverría M.G. (2008). Caracterización de secuencias del virus de la arteritis equina obtenidas directamente de muestras de semen de equinos seropositivos. Analecta Veterinaria, 28 (2), 21-26.

7. Vissani A., Iglesias M., Echeverría M.G., Tordoya S., La Torre J., Metz G., Becerra L., Serena S., Olguin Perglione C. \& Barrandeguy M. (2008). - Equine viral arteritis: current status in Argentina. 2nd International Workshop on Equine Viral Arteritis, 13-15 October, Lexington, Kentucky.

8. Stadejek T., Bjorklund H., Ros Bascunana C., Ciabatti I.M., Scicluna M.T., Amaddeo D., McCollum W.H., Autorino G.L., Timoney P.J., Paton D.J., Klingeborn B. \& Belak S. (1999). - Genetic diversity of equine arteritis virus. J. gen. Virol., 80 (3), 691-699.

9. Larsen L.E., Storgaard T. \& Holm E. (2001). - Phylogenetic characterization of the GL sequences of equine arteritis virus isolated from semen of asymptomatic stallions and fatal cases of equine viral arteritis in Denmark. Vet. Microbiol., 80 (4), 339-346

10. Hornyak A., Bakonyi T., Tekes G., Szeredi L. \& Rusvai M. (2005). - A novel subgroup among genotypes of equine arteritis virus: genetic comparison of 40 strains. J. vet. med. Sci., B, 52 (3), 1-7.

11. Metz G.E., Ocampos G.P., Serena M.S., Gambaro S.E., Nosetto E. \& Echeverría M.G. (2011). - Extended phylogeny of the equine arteritis virus sequences including South American sequences. Intervirology, 54 (1), 30-36.

12. Echeverría M.G., Díaz S., Metz G.E., Serena M.S., Panei C.J. \& Nosetto E. (2010). - Evaluation of neutralization patterns of the five unique Argentine equine arteritis virus field strains reported. Rev. argent. Microbiol., 42 (1), 11-17.

13. Zhang J., Timoney P., Shuck K., Seoul G., Go Y., Lu Z., Powell D.G., Meade B.J. \& Balasuriya U.B. (2010). - Molecular epidemiology and genetic characterization of equine arteritis virus isolates associated with the 2006-2007 multi-state disease occurrence in the USA. J. gen. Virol., 91 (9), 2286-2301.

14. Pronost S., Pitel P.H., Miszczak F., Legrand L., Marcillaud-Pitel C., Hamon M., Tapprest J., Balasuriya U.B., Freymuth F. \& Fortier G. (2010). - Description of the first recorded major occurrence of equine viral arteritis in France. Equine vet. J., 42 (8), 713-720.

15. Gryspeerdt A., Chiers K., Govaere J., Vercauteren G., Ducatelle R., Van de Walle G.R. \& Nauwynck H.J. (2009). Neonatal foal death due to infection with equine arteritis virus in Belgium. Vlaams diergeneesk. Tijdschr., 78, 189-193.
16. Olguin Perglione C., Córdoba M., Echeverría M.G., Timoney P., Tordoya S., Darqui F., Metz G.E., Miño S., Becerra L., Serena M.S., Vissani A., González E.T., Silvestrini M.P., Corva S., Uncal L., Dayraut J., Badaracco A. $\&$ Barrandeguy M. (2010). - Equine viral arteritis outbreak in Argentina. In Proc. 114th Annual Meeting of the United States Animal Health Association, 12-16 November, Minneapolis, Minnesota.

17. Timoney P.J., McCollum W.H. \& Roberts A.W. (1987). Detection of the carrier state in stallions persistently infected with equine arteritis virus. Proc. Am. Assoc. Equine Pract., $32,57-65$

18. Mittelholzer C., Stadejek T., Johansson I., Baule C., Ciabatti I., Hannant D., Paton D., Autorino G.L., Nowotny N. \& Belak S. (2006). - Extended phylogeny of equine arteritis virus: division into new subgroups. J. vet. Med., B, 53 (2), $55-58$.

19. Hall T.A. (1999). - BioEdit: a user friendly biological sequences alignment editor and analysis program for Windows 95/98/NT. Nucl. Acids Symp. Ser., 41, 95-98.

20. Tamura K., Dudley J., Nei M. \& Kumar S. (2007). - MEGA4: molecular evolutionary genetic analysis (MEGA) software version 4.0. Molec. Biol. Evol., 24 (8), 1596-1599.

21. Zhang J., Miszczak F., Pronost S., Fortier C., Balasuriya U.B., Zientara S., Fortier G. \& Timoney P.J. (2007). - Genetic variation and phylogenetic analysis of 22 French isolates of equine arteritis virus. Arch. Virol., 152 (11), 1977-1994.

22. Larska M. \& Rola J. (2008). - Molecular epizootiology of equine arteritis virus isolates from Poland. Vet. Microbiol., 127 (3-4), 392-398

23. Zhang J., Go Y.Y., MacLachlan N.J., Meade B.J., Timoney P.J. \& Balasuriya U.B.R. (2008). - Amino acid substitutions in the structural or nonstructural proteins of a vaccine strain of equine arteritis virus are associated with its attenuation. Virology, 378 (2), 355-362.

24. Balasuriya U.B.R., Go Y.Y. \& MacLachlan N.J. (2013). Equine arteritis virus. Vet. Microbiol., 167 (1-2), 93-122.

25. Vairo S., Vandekerckhove A., Steukers L., Glorieux S., Van den Broeck W. \& Nauwynck H. (2012). - Clinical and virological outcome of an infection with the Belgian equine arteritis virus strain 08P178. Vet. Microbiol., 157 (3-4), $333-344$

26. Vairo S., Saey V., Bombardi C., Ducatelle R. \& Nauwynck H. (2014). - The recent European isolate (08P178) of equine arteritis virus causes inflammation but not arteritis in experimentally infected ponies. J. comp. Pathol., 151 (2-3), 238-243. doi:10.1016/j.jcpa.2014.04.008.

27. Del Piero F. (2000). - Equine viral arteritis. Vet. Pathol., 37 (4), 287-296 